\title{
Organising Traditional Knowledge for Inclusive Development : Role of Libraries
}

\author{
Ratna Bandyopadhyay ${ }^{1}$ \\ and \\ Krishnapada Majumder ${ }^{2}$
}

\begin{abstract}
In this paper we discuss traditional knowledge, its importance especially in inclusive development and knowledge management activities taken up in West Bengal. We also focus on the role of libraries especially public libraries in preserving and propagating this cultural heritage and traditional knowledge.
\end{abstract}

Keywords: Traditional knowledge, Knowledge management, West Bengal, Libraries.

\section{Nature of Traditional Knowledge}

The Director General of UNESCO has stated the following about traditional knowledge: "The indigenous people of the world possess an immense knowledge of their environments, based on centuries of living close to nature. Living in and from the richness and variety of complex ecosystems, they have an understanding of the properties of plants and animals, the functioning of ecosystems and the techniques for using and managing them that is particular and often detailed. In rural communities in developing countries, locally occurring species are relied on for many - sometimes all - foods, medicines, fuel, building materials and other products. Equally, people's knowledge and perceptions of the environment, and their relationships with it, are often important elements of cultural identity."[8]

Traditional knowledge is based on the practical experiences of common people, deep rooted in the life of the people of the community. This has been transmitted verbally through generations. It has become part of their life. This knowledge is implicit and difficult to organize. But proper organization of this knowledge is necessary as it shows the way for comprehensive social and economic development of the community as well as of the nation as a whole. The traditional knowledge can range from environment conservation, Health maintenance/ preservation, medicine practices, sustaining agricultural practices, etc. The

${ }^{1}$ Professor, Library and Information Science, University of Calcutta, India. E-mail: rdas@hotmail.com ${ }^{2}$ Professor, Library and Information Science, Jadavpur University, India. 


\section{Bangladesh Journal of Library and Information Science}

direct interaction with natural environment give them the opportunity to have practical knowledge regarding various aspects like medicinal, nutritional values of plants, how to cure certain illness or how to prevent certain types of diseases by using specific types of herbs, understanding the weather, chemical properties of soil in cultivating different types of crops, etc. There are about 40 tribes in West Bengal constituting 5.5\% of the total population of West Bengal, which is more than 80 million.[1,20] The cultural diversity is observed among these communities. Each and every community of this multi-cultural society has its own traditional culture. Some of these tribes are on the verge of extinction. It has been found that there are 4 tribes with population less than 1000 [6].

Different types of traditional art have become indicators of cultural identity of different communities. 'Baul' songs were generally sung with 'ek tara', 'Bhatiyali' songs were usually sung by the boatmen, 'Bhaoyaiya' songs were very popular at one time. Similarly 'Gambhira dance of North Bengal, 'Chhau dance' of Purulia were renowned folk dances.[3] These traditional folk cultures used to be transmitted through 'guru' and 'shishya' tradition/ parampara. Some festivals of certain tribal communities used to be celebrated with colourful grandeur, for example 'Tusu', 'Bhadu', 'Baha', etc.[4] Different traditional songs, dances , music with traditional instruments were part of these festivals. This is virtually on its way out. People engaged in the profession of reciting folk lore or narrating tales in important places were known as 'Kathaks' and 'Vachaks'.[3] They used to carry the tradition orally. Now these people are rarely seen. Preservation of this cultural heritage as well as propagation of this heritage are needed. Time is fast changing and we need to preserve our culture. The development of information technology has given us the opportunity to use it properly in preserving and disseminating this cultural heritage.

\section{Importance of Traditional Knowledge}

Traditional knowledge can be used in tackling certain types of problems, natural calamities and drawing plans for the development of local areas. An adverse effect of globalization is the trend to accept only the modern western practices. But for the sustenance of traditional knowledge it should be preserved, integrated and be used in the overall development of the nation. With the help of IT now it is possible to integrate the traditional practices of various communities, to create databases, to develop resource centres, and develop network.

The importance of traditional knowledge is best expressed in a press release of UN/ISDR 2008 dated $19^{\text {th }}$ September 2008. It states "When the Indian Ocean Tsunami hit in December 2004, over 250,000 people were killed throughout Asia, but only seven people died out of a population of approximately 83,000 on Simeulue Island, just $40 \mathrm{~km}$ from the epicenter of the earthquake. Nearly the entire population of the Island survived. Thanks to the people's inherited knowledge of Tsunamis handed down from each generation to the next."[9]

"The Onge tribe, for example, have lived on Little Andaman for between 30,000 and 50,000 years and, though they are on the verge of extinction, almost all of the 100 or so people left seem to have survived the 26 December quake and the devastating waves which followed. Their folklore talks of huge shaking of ground followed by high wall of water. "[5] Manish Chandi, anthropologist also added "... Jarawa tribe ... was also largely safe." K.C.Ghoshal,the then executive secretary of the Andaman-Nicobar tribal welfare department further added “...the Sentinelese people appear not to have been affected."[5] 
In Canada ecological knowledge of aboriginal communities gave valuable insights and helped in the management of natural resources and ecological planning. [14]

So, the preservation of traditional knowledge is absolutely necessary to find out effective ways to combat natural calamities, to plan for the development of local areas, to maximize the use of natural resources and plan for sustenance and overall development of the nation. This is the time to seek out ways to foster care for protecting and preserving this knowledge so that the present as well as future generations can reap the benefit and these communities can also continue to exist , flourish and accrue fair share of the benefits.

\section{Inclusive Development}

"Inclusive development is development that marginalized groups take part in and benefit from, regardless of their gender, ethnicity, age, sexual orientation, disability or poverty. It seeks to address the deepening inequality across the world that has arisen despite unprecedented economic growth." [12]

Inclusive Development Is now being considered as the prime factor for the socio- economic development of a country like ours. Harmonious development can only be achieved by attending to the needs of all especially of the disadvantaged ones, making use of their skills, chalking out their developmental programmes, building as well as sustaining their skills, encouraging in the production of traditional skill and knowledge based products and services, helping for the distribution, dissemination of these products and services through various ways. These knowledge based products and services can help them to generate the livelihood and thus meet their social needs. India has given stress on inclusive development in the eleventh five year plan (2007-12).

\section{Problems associated with traditional knowledge}

The problems associated with traditional knowledge are as follows:

- We have already mentioned that some of the tribal communities (having traditional knowledge, distinct cultures) are on the verge of extinction

4 tribes with less than 1000 population

9 tribes with population between 1000 to 5000

5 tribes with population between 5000 to 10000 [6]

- Cultural identities of some of the communities are eroding because of the socio economic pressures, effect of globalization, growing opportunities in the job markets, change lifestyle, migration from homeland, etc.

- This knowledge is implicit. Most of it is not available in written form.

- Changed lifestyle may also weaken the knowledge transfer process to future generations.

- There is dearth of respect and appreciation for this knowledge. Lack of awareness leads to misunderstanding and fails to realize the true value i.e. its scientific and technical qualities

- Preservation of this knowledge

- Protection of this knowledge against misuse - Commercial exploitation of knowledge by third parties.

\section{Knowledge Management Activities}

Different government departments, research institutions, non government organizations are trying to document traditional knowledge and also bringing out various print and non print 


\section{Bangladesh Journal of Library and Information Science}

documents on folk art , music, dance, their crafts and craftsmanship, traditional indigenous knowledge as well as on physical anthropological aspects.

Research Institutions like Anthropological Survey of India (ASI) have taken up different research programmes to give a new insight to biocultural study and to find out the effect of mixing up of various cultures in a multicultural population. Other government departments like Scheduled Castes and Tribes Welfare Department, Government of West Bengal; Lokasanskriti Gabeshana Parishad (Research Institute of Folk Culture, West Bengal); Loksanskriti o Adibasi Sanskriti Kendra (Folk Culture and Tribal Culture Centre), Information and Culture Department, Government of West Bengal, etc., different organizations like Zonal Cultural Centres (ZCC), Sangeet Natak Akademi, Lalit Kala Akademi, etc. are also doing the work of documentation and bringing out documents in both print and non-print media. Some departments of different Universities like Department of Anthropology, University of Calcutta, are also doing the documentation work to preserve the cultural heritage. Library and Information Science departments of some universities in West Bengal are also taking up projects to assess the information needs of the tribal communities residing in different parts of the state.

The methods of preserving cultural heritage range from preparation of written/ printed documents, non print documents covering audio-visual recording, photographs, preserving artefacts and sponsoring teacher-disciple or guru-shishya transmission methods, etc.

Besides Archives, Museums, Research Centres, Govt. deptartments, Universities, NGOs, Libraries of these centres, organizations are also playing important roles in documenting, preserving and disseminating the traditional knowledge and cultural heritage. Traditional Knowledge Digital Library (TKDL) has already 'documented over 200,000 formulations of Ayurveda, Siddha and Unani to save them from piracy.'[15]

Indira Gandhi National Centre for the Arts (IGNCA) is developing a databank on Arts, Humanities and cultural heritage of the country. The Indian National Trust for Art and Cultural Heritage (INTACH) is also trying to preserve traditional culture. Government departments are also organizing various fairs exhibitions to promote traditional art and culture .

Libraries can also take part in the present knowledge management activities and coordinate these for optimal use. Here we give some suggestions on how libraries especially public libraries work in this direction.

\section{Public library system in West Bengal}

The state of West Bengal has a public library system with 2821 libraries and community library cum information centres (CLICs). The Government of West Bengal aims to provide one public library in each gram panchyat, which is the basic administrative units in West Bengal. There are 3362 gram panchyats. Out of these only about 1722 gram panchyats have rural public libraries and in another 341 gram panchyats the government has developed Community Library cum Information Centres (CLICs).[2] So majority of gram panchyats are being served by government sponsored public libraries/ information centres.

There are also about 2200 registered but non-government and non-sponsored libraries in this state. Some of these get financial assistance from the state government. Many of these public libraries are actively doing surveys of local areas and organising local history collections and also aiming at preserving the cultural heritage of target population including local communities. 


\section{Bangladesh Journal of Library and Information Science}

Rabindranath Tagore had initiated the development of Rural areas when he founded VisvaBharati University. Now Tagore's dream is being fulfilled by Visva-Bharati University with assistance from Raja Rammohan Roy Library Foundation (RRRLF). 36 village libraries are now serving as community centres. These are acting as village community centres, engaged in promoting indigenous knowledge, art, crafts for their sustenance and development. These centres are also acting as continuing education centres for neo literates, hands-on training centres for transferring the tradition to generations, etc. [1, 16].

Some of the public libraries in West Bengal are trying to document the history and culture of the local areas/communities. Thus they are playing a role to preserve the cultural heritage of the local areas and also disseminating these knowledge as and when these are required.

Libraries are supposed to assess the need of the target population and satisfy their needs. They should also collect, record and prepare database/s on the local history and culture along with their demographic characteristics. The literacy rate in West Bengal is $69.2 \%$ and literacy rate of tribal population is $43 \% .[1,20]$ So Audio-visual recording is necessary to reach the masses, to support information needs of the community.

\section{IPR Issues}

"Copyright protection is above all one of the means of promoting, enriching and disseminating the national cultural heritage. A country's development depends to a very great extent on the creativity of its people, and encouragement of individual creativity and its dissemination as a sine qua non for progress.” [21]

The protection policy should think of practical benefits of the holders of traditional knowledge. We need to recognize and respect the rights of traditional knowledge holders as well as we have to be conscious about the unauthorized use of traditional knowledge by others. Two types of protection systems for traditional knowledge have been developed

Positive protection - This gives the indigenous knowledge holders the right to seek action against any misuse of this knowledge

Defensive protection - This prevents others in taking illegitimate rights on traditional knowledge. Traditional knowledge should be organized and put in the public domain to avoid illegitimate use of it.

Other legal concepts which have developed regarding protection of traditional knowledge are Prior Informed Consent (PIC) which asks for consultation with the holders of this indigenous knowledge before this knowledge is accessed or used;

Equitable benefit sharing which stresses on the equal share of the benefits coming out of the use of traditional knowledge;

Unfair competition - This asks for taking action against any false claim of any product as indigenous.

Besides this the holders of the traditional knowledge can apply for patent rights to protect their innovative knowledge. The distinctive marks, symbols, signs, terms used in association with indigenous knowledge can also be protected. Some countries like Brazil, Costa Rica, India, Peru, Philipines, Burma, and others are developing sui generis laws to protect some parts of traditional knowledge. India has also amended patent law to add a clarification for traditional knowledge. International cooperation and coordination in this regard is necessary. WIPO is providing a 


\section{Bangladesh Journal of Library and Information Science}

platform for developing policies for protecting traditional knowledge and cultural heritage. The Intergovernmental Committee on Intellectual Property and Genetic Resources, Traditional Knowledge and Folklore of WIPO established in 2001 is thinking of increased protection of indigenous knowledge against misuse. WIPO has also issued 'Guide on Managing International Property for Museums'[17]. It also helps in managing IP of libraries, archives engaged in preserving cultural heritage and other traditional knowledge.

\section{Awareness programmes}

Though a number of research organizations and government departments have taken up projects for preserving the heritage, we need more projects for recording various art forms, cultural lives in multimedia digitized format directly from the communities. Librarians of public libraries can help in identifying the communities, assessing their needs and jointly supervising and conducting the digitization work, organizing these and providing these digitized services with audio-visual content. For this, we need to organize awareness programmes, training programmes for handling computers and providing these services.

To prepare our future librarians we should provide training in content generation and management. They should also be trained to act as knowledge centre managers, to handle necessary equipments. Librarians should be trained in soft skills. They should be trained to develop good relations with the target population and should try to learn and record this knowledge.

Public libraries in West Bengal have a developed system. With the help of ICT these libraries can coordinate already available materials and can provide better services and work in the development of the communities. The library should support the needs of the community with the help of audio-visual materials especially where the literacy level is low. A multilingual and multicultural country like ours urgently needs to translate these $\mathrm{A} / \mathrm{V}$ materials for use in different parts of the country. Besides these $\mathrm{A} / \mathrm{V}$ materials, computerized integrated databases need to be created for its sustenance and development. These databases should provide access and share the knowledge thus stored. A network is also to be developed. The librarians should have proper training to have awareness of traditional knowledge, to do the field survey, capture data, knowledge of handling information technology and should be aware of the IP protection policy.

\section{Conclusion}

With the developed public library system in West Bengal we can take more initiatives to assess the need of the local communities, appreciate the traditional culture and indigenous knowledge and preserve this cultural heritage. Public libraries especially the rural libraries should take steps in collecting demographic characteristics including the lifestyle, culture of the target population and record this live with the help of audio visual technology. Audio as well as video cassettes, CDs can be prepared and can be kept in local libraries. Considering the low literacy level, we have to do door to door survey and preserve this in multi media. Translation of this cultural heritage of the multilingual communities to other regional languages will help in the exchange of cultural diversity. Libraries should cooperate with other research institutions, government departments, non-government organisations in promoting fairs, festivals and thus in disseminating cultural heritage. The well organized public library system can be used to remove the cultural barriers and to form the base for unity in diversity. 


\section{Bangladesh Journal of Library and Information Science}

\section{References}

1. Bandyopadhyay, Ratna Sharing traditional knowledge and culture of different tribes of West Bengal, India. (IFLA World library and information congress, $74^{\text {th }}$, Quebec City, Canada, 2008)

2. Bandyopadhyay, Ratna \& Majumder, K.P. Some directions for digitized services with audio visual content for the public libraries of West Bengal, India. (IFLA World library and information congress, 72nd, Seoul, 2006)

3. Basu, Sambit. Folklore of Bengal. http://userpages.umbe.edu/ achattl/folk.html

4. Basu, Sunil Kumar. A Note on important festivals among the major tribals of West Bengal.( In Das, A.K. \& others. West Bengal tribes; 418-439)

5. Bhaumik, Subir Tsunami folklore 'saved islanders’.(http://newsvote.bbc.co.uk/mpspps/pagetools/print/news.bbc.co.uk/2/hi )

6. Chowdhuri, M. K. and others. Ethnographic notes on the scheduled tribes of West Bengal. Kolkata: Cultural Research Institute, 2003.

7. Das, A.K. and others. West Bengal tribes: socio economic and cultural life. Calcutta: Cultural Research Institute on behalf of Scehduled Castes and Tribes Welfare Department, Government of West Bengal, 1991.

8. http://www.nativescience.org/issues/tk.htm viewed on 13.12 .09

9. http://www.preventionweb.net/english/professional/news/v.php?id=3642 viewed on 17.12.09

10. http://www.scidev.net/en/news/digital-library-to-protect-indigenous-knowledge.html viewed on 13.12.09

11. http://www.sristi.org/ems/griid/ viewed on 17.12 .09

12. http://www.undp.org/poverty/focus_inclusive_development.shtml viewed on 17.12.09

13. http://www.wipo.int/tk/en viewed on 27.12 .09

14. http://www.wipo.int/export/sites/www/freepublications/in/tk/920/wipo_pub_920.pdf viewed on 15.12.09

15. Indian traditional knowledge digital library:website of Ayurveda, Siddha and Unani (http://www.hindu-blog.com/2009/02/indian-traditional-knowledge-digi)

16. Nandi, S.G. Rural development, library and Rabindranath. (In Information support for rural development :Proceedings of 21 National Seminar of IASLIC, 2004-5, Jadavpur University, Kolkata)

17. Panatalony, R.E. WIPO Guide on managing international property for museums. (http://www.wipo.int/copyright/en/museums_ip/) viewed on 27.12.2009.

18. West Bengal. Department of School Education. Annual report 2005-2006. 2007.

19. West Bengal. Directorate of Library Services. Annual report 2003-2004.

20. West Bengal. Primary census abstract. 2001.

21. World Intellectual Property Organisation. WIPO intellectual property handbook Law, policy and use. WIPO Pub No.489(E) (http://www.wipo.int) viewed on 27.12.2009. 